\title{
Aminomonas paucivorans gen. nov., sp. nov., a mesophilic, anaerobic, amino-acid-utilizing bacterium
}

\author{
S. Baena, ${ }^{1,2}$ M.-L. Fardeau, ${ }^{1}$ B. Ollivier, ${ }^{1}$ M. Labat, ${ }^{1}$ P. Thomas, ${ }^{3}$ \\ J.-L. Garcia ${ }^{1}$ and B. K. C. Patel ${ }^{4}$
}

Author for correspondence: B. K. C. Patel. Tel: +61 417726 671. Fax: +61738757656. e-mail: bharat@genomes.sci.gu.edu.au

\footnotetext{
1 Laboratoire ORSTOM de Microbiologie des Anaérobies, Université de Provence, CESB/ESIL Case 925, 163 Avenue de Luminy, 13288 Marseille Cedex 09, France

2 Departamento de Biologia, Pontificia Universidad Javeriana, POB 56710, SantaFe de Bogota, Colombia

3 Département de Biologie, Université de la

Mediterranée, 13288

Marseille Cedex 09, France

4 School of Biomolecular and Biomedical Sciences, Faculty of Science and Technology, Griffith University, Nathan, Brisbane 4111, Australia
}

\begin{abstract}
A novel, asaccharolytic, amino-acid-degrading bacterium, designated strain GLU-3', was isolated from an anaerobic lagoon of a dairy wastewater treatment plant. Strain GLU-3' stained Gram-negative and was an obligately anaerobic, non-spore-forming, slightly curved, rod-shaped bacterium $(0.3 \times 4.0-6.0 \mu \mathrm{m})$ which existed singly or in pairs. The DNA G+C content was 43 mol\%. Optimum growth occurred at $35{ }^{\circ} \mathrm{C}$ and pH 7.5 on arginine with a generation time of $16 \mathrm{~h}$. Good growth was obtained on arginine, histidine, threonine and glycine. Acetate was the end-product formed from all these substrates, but in addition, a trace of formate was detected from arginine and histidine, and ornithine was produced from arginine. Strain GLU-3' grew slowly on glutamate and produced acetate, carbon dioxide, formate, hydrogen and traces of propionate as the end-products. In syntrophic association with Methanobacterium formicicum, strain GLU-3' oxidized arginine, histidine and glutamate to give propionate as the major product; acetate, carbon dioxide and methane were also produced. Strain GLU-3' did not degrade alanine and the branched-chain amino acids valine, leucine and isoleucine either in pure culture or in association with $\boldsymbol{M}$. formicicum. The nearest phylogenetic relative of strain GLU-3 ${ }^{\top}$ was the thermophile Selenomonas acidaminovorans (similarity value of $89.5 \%$ ). As strain GLU-3 ${ }^{\top}$ is phylogenetically, physiologically and genotypically different from other amino-acid-degrading genera, it is proposed that it should be designated a new species of a new genus Aminomonas paucivorans gen. nov., sp. nov. (DSM 12260').
\end{abstract}

Keywords: Aminomonas paucivorans, anaerobic bacterium, amino acid degradation, mixed culture, Methanobacterium formicicum

\section{INTRODUCTION}

In nature, proteins are hydrolysed to peptides and amino acids and converted to methane and $\mathrm{CO}_{2}$ by mixed bacterial populations under anaerobic conditions. A large number of peptides and amino acids can serve as carbon and energy sources for saccharolytic and asaccharolytic anaerobic bacteria (Smith \& MacFarlane, 1997) and for many years, it was assumed that saccharolytic bacteria were primarily responsible

The GenBank accession numbers for the rRNA gene sequences of Aminomonas paucivorans strain GLU- ${ }^{\top}$, Selenomonas acidaminovorans and 'Selenomonas acidaminophila' are AF072581, AF071414 and AF071415, respectively. for amino acid and peptide degradation (McInerney, 1988). However, studies on the rumen ecosystem have provided evidence of the importance of asaccharolytic micro-organisms in the turnover of amino acids (Chen \& Russell, 1988, 1989). The descriptions of new species of obligate amino acid degraders isolated from a wide range of other ecosystems clearly indicate that their importance may have been largely unnoticed. Examples of asaccharolytic peptide/amino-acid-degrading bacteria include Clostridium aminophilum from the rumen (Paster et al., 1993), Eubacterium acidaminophilum from black anaerobic mud of a waste water ditch (Zindel et al., 1988), Acidaminobacter hydrogenoformans from Ems-Dollard estuary mud (Stams \& Hansen, 1984), 'Selenomonas acidaminophila' from an anaerobic purification plant 
(Nanninga et al., 1987) and Dethiosulfovibrio peptidovorans from an oilfield (Magot et al., 1997).

As part of our investigations on the degradation of peptides and amino acids, we have isolated different asaccharolytic amino-acid-degrading anaerobic bacteria from a treatment plant of a dairy wastewater anaerobic lagoon typically rich in proteins. In this report, we describe a new glutamate-degrading strain, designated GLU $-3^{\mathrm{T}}$, which is substantially different from those reported previously.

\section{METHODS}

Sample source. A sample was collected from an anaerobic lagoon of a dairy wastewater treatment plant (SantaFe de Bogota, Colombia) by completely filling a sterile bottle with a sediment slurry. The in situ temperature at the sample collection point was $24^{\circ} \mathrm{C}$ and the $\mathrm{pH}$ was $6 \cdot 8$. Samples were transported to the laboratory and maintained at $4^{\circ} \mathrm{C}$ until used.

Source of strains. Methanobacterium formicicum DSM 1535 , S. acidaminovorans DSM $6589^{\mathrm{T}}$ and ' $S$. acidaminophila' DSM $3853^{\mathrm{T}}$ were purchased from DSMZ (Deutsche Sammlung von Mikroorganismen und Zellkulturen, Braunschweig, Germany).

Media and cultivation conditions. The Hungate technique (Hungate, 1969) was used throughout these studies. The basal medium used for isolation and cultivation of strain GLU-3 ${ }^{\mathrm{T}}$ contained $\left(1^{-1}\right): 0 \cdot 2 \mathrm{~g} \mathrm{KH}_{2} \mathrm{PO}_{4} ; 0 \cdot 3 \mathrm{~g} \mathrm{NH}_{4} \mathrm{Cl} ; 1 \cdot 0 \mathrm{~g}$ $\mathrm{NaCl} ; 0.4 \mathrm{~g} \mathrm{MgCl}_{2} .6 \mathrm{H}_{2} \mathrm{O} ; 0.5 \mathrm{~g} \mathrm{KCl} ; 0 \cdot 15 \mathrm{~g} \mathrm{CaCl}_{2} .2 \mathrm{H}_{2} \mathrm{O}$; $1 \mathrm{ml}$ trace element solution (Imhoff-Stuckle \& Pfenning, $1983) ; 1.0 \mathrm{ml} 0 \cdot 1 \%$ resazurin. The $\mathrm{pH}$ was adjusted to $7 \cdot 2$ with $10 \mathrm{M} \mathrm{KOH}$. The medium was boiled under a stream of $\mathrm{O}_{2}$-free $\mathrm{N}_{2}$ gas and cooled to room temperature. Aliquots $(5 \mathrm{ml})$ of the medium were distributed into Hungate tubes under a stream of $\mathrm{O}_{2}$-free $\mathrm{N}_{2}$ gas. The gas phase was subsequently replaced with $\mathrm{N}_{2} / \mathrm{CO}_{2}(80: 20)$. Prior to inoculation, $0.15 \mathrm{ml} 2 \% \mathrm{Na}_{2} \mathrm{~S} .9 \mathrm{H}_{2} \mathrm{O}, 0.25 \mathrm{ml} 10 \% \mathrm{NaHCO}_{3}$ and $0.05 \mathrm{ml}$ Balch vitamin solution (Balch et al., 1979) were injected into each tube. Amino acids were added from sterile (heat or filter-sterilized) anaerobic stock solutions. The ability of the strain to grow aerobically was tested in the same growth medium but that was prepared aerobically and lacked $\mathrm{Na}_{2} \mathrm{~S} \cdot 9 \mathrm{H}_{2} \mathrm{O}$.

Isolation and growth. For isolation, the sludge sample was pulverized in an anaerobic chamber using a hand-held homogenizer. A tenfold serial dilution was prepared and inoculated into the Hungate tubes containing $5 \mathrm{ml}$ basal medium with glutamate and yeast extract at final concentrations of $10 \mathrm{mM}$ and $0.2 \%$, respectively. Incubations were performed at $37^{\circ} \mathrm{C}$ for up to $3-4$ weeks, after which serial dilutions were prepared from the dilution which showed growth and inoculated into Hungate roll tubes containing basal medium, yeast extract $(0 \cdot 2 \%)$, glutamate $(10 \mathrm{mM})$ and agar $(2 \%)$. Axenic cultures were obtained by the repeated use of the Hungate roll-tube method.

Microscopy. Cell morphology and motility were determined using a Nikon phase-contrast microscope. Cells from cultures grown under different conditions and with different substrates were examined for the presence of spores. Thin sections and negative-staining of exponentially growing cells were prepared and examined as previously described (Fardeau et al., 1997).

Determination of $\mathrm{pH}$, temperature and $\mathrm{NaCl}$ requirements for growth. All experiments were conducted in duplicate in basal medium containing $10 \mathrm{mM}$ arginine and $0.2 \%$ yeast extract unless otherwise indicated. The isolate was subcultured at least once under the same experimental conditions. For $\mathrm{pH}$ studies, the medium was adjusted with sterile anaerobically prepared stock solutions of $\mathrm{HCl}(1 \mathrm{M})$, $\mathrm{NaHCO}_{3}(10 \%)$ or $\mathrm{Na}_{2} \mathrm{CO}_{3}(10 \%)$ to give a $\mathrm{pH}$ of $5 \cdot 7-9 \cdot 2$. The temperature range for growth was determined at $18-55^{\circ} \mathrm{C}$. For studies on $\mathrm{NaCl}$ requirements, $\mathrm{NaCl}$ was weighed directly into tubes for concentrations higher than $1 \% \mathrm{NaCl}$ and the medium was dispensed into the tubes as described above. For concentrations lower than $1 \%$, different amounts of a stock solution of $\mathrm{NaCl}(10 \%)$ were injected into predispensed medium to give the required concentrations.

Substrate utilization tests. The isolate was subcultured at least once under the same experimental conditions. For substrate utilization studies, $0 \cdot 2 \%$ yeast extract was added to the basal medium. L-Amino acids, organic acids and sugars were tested at a final concentration of $10 \mathrm{mM}$. Mesaconate, $\beta$-methylaspartate, oxaloacetate, glycerol and ethanol were added to a final concentration of $5 \mathrm{mM}$. Biotrypcase, peptone, Casamino acids, gelatin and casein were tested at a final concentration of $0.5 \%(\mathrm{w} / \mathrm{v})$. The electron acceptors tested were: thiosulfate $(10 \mathrm{mM})$, sulfate $(10 \mathrm{mM})$, elemental sulfur $(2 \%)$, sulfite $(2 \mathrm{mM})$, sodium fumarate $(20 \mathrm{mM})$ and nitrate $(10 \mathrm{mM})$.

Mixed culture experiments. To establish whether strain GLU-3 ${ }^{\mathrm{T}}$ could benefit in the presence of hydrogen scavenging bacteria, a mixed culture with the hydrogenotrophic methanogen, $M$. formicicum was prepared. $M$. formicicum was grown under a $\mathrm{H}_{2} / \mathrm{CO}_{2}(80: 20)$ atmosphere in basal medium containing $0.1 \%$ yeast extract, $10 \mathrm{mM}$ acetate and $30 \mathrm{mM}$ formate. Strain GLU-3 ${ }^{\mathrm{T}}$ was grown in the basal medium containing $10 \mathrm{mM}$ arginine and $0.2 \%$ yeast extract. A $10 \%$ inoculum from each of the cultures was injected into tubes containing $5 \mathrm{ml}$ basal medium, $0.2 \%$ yeast extract and one of a selected amino acid (alanine, glutamate, valine, isoleucine, leucine, glycine, histidine, threonine or arginine) or organic acid (pyruvate, fumarate, succinate, $\alpha$-ketoglutarate or malate) at a concentration of $10 \mathrm{mM}$. At the end of the incubation period of $2-3$ weeks at $37^{\circ} \mathrm{C}$, the concentrations of amino acids utilized and the end-products formed were determined. Basal medium amended with only $0.2 \%$ yeast extract was used as a control.

Growth of strain GLU-3 ${ }^{\top}$ under a hydrogen atmosphere. The effect of a hydrogen atmosphere $\left(\mathrm{H}_{2} / \mathrm{CO}_{2} ; 80: 20\right)$ on growth of strain GLU- $3^{\mathrm{T}}$ was tested using basal medium containing $0.2 \%$ yeast extract and $10 \mathrm{mM}$ arginine, glutamate, threonine, histidine or glycine.

Analytical techniques. Growth was measured by inserting growth tubes directly into a model UV-160A spectrophotometer (Shimadzu) and measuring $\mathrm{OD}_{580}$. The fermentation end-products were determined as described by Fardeau et al. (1993). Amino acid concentrations were determined by liquid chromatography (Moore et al., 1958). Growth and product formation were analysed after 2-3 weeks incubation at $37^{\circ} \mathrm{C}$. Heat resistance was determined by incubating the culture at $80^{\circ} \mathrm{C}$ for up to $20 \mathrm{~min}$ and at $90^{\circ} \mathrm{C}$ for up to $10 \mathrm{~min}$ followed by subculturing in fresh growth medium.

Determination of $\mathbf{G}+\mathbf{C}$ content. The $\mathrm{G}+\mathrm{C}$ content was determined by the DSMZ. The DNA was isolated and purified by chromatography on hydroxyapatite. The $\mathrm{G}+\mathrm{C}$ content was determined by HPLC as described Mesbah $e t$ al. (1989). 
DNA extraction and amplification of 16S rRNA. S. acidaminovorans (Guangsheng et al., 1992) and 'S. acidaminophila' (Nanninga et al., 1987) were cultured as described previously and strain GLU-3 $3^{\mathrm{T}}$ was grown on the basal medium containing $0.2 \%$ yeast extract and $10 \mathrm{mM}$ glutamate. The DNA was extracted from the strains as described previously (Andrews \& Patel, 1996; Redburn \& Patel, 1993). The universal primers Fdl and Rdl were used to obtain a PCR product of approximately $1.5 \mathrm{~kb}$, corresponding to base positions 8-1542 based on Escherichia coli numbering of the 16S rDNA (Van de Peer \& De Wachter, 1993). A $50 \mu \mathrm{l}$ reaction mix contained $1-20 \mathrm{ng}$ genomic DNA, $1 \mu \mathrm{M}$ each primer, $5 \mu \mathrm{l} 10 \times$ buffer, $200 \mu \mathrm{M}$ dNTP, $3.5 \mathrm{mM} \mathrm{MgCl}_{2}$ and $2.5 \mathrm{U}$ Taq polymerase (Promega). PCR was carried out by an initial denaturation at $94^{\circ} \mathrm{C}$ for $7 \mathrm{~min}$, then 29 cycles of annealing at $55^{\circ} \mathrm{C}$ for $2 \mathrm{~min}$, extension at $72^{\circ} \mathrm{C}$ for $4 \mathrm{~min}$, denaturation at $94^{\circ} \mathrm{C}$ for $1 \mathrm{~min}$, and finally an extension cycle of $55^{\circ} \mathrm{C}$ for $2 \mathrm{~min}$ and $72^{\circ} \mathrm{C}$ for $20 \mathrm{~min}$.

Direct sequencing of PCR products. PCR products were purified using the QIAquick kit (Qiagen). DNA concentration of purified PCR products was estimated by comparison with the Low Mass Ladder (Gibco-BRL) on an agarose gel containing ethidium bromide. PCR products were sequenced with the ABI PRISM Dye Terminator Cycle Sequencing kit with AmpliTaq FS DNA polymerase and an ABI $373 \mathrm{~A}$ sequencer. A $10 \mu \mathrm{l}$ reaction mix contained $35 \mathrm{ng}$ PCR product, $4 \mu \mathrm{l}$ cycle sequencing reaction mix, $3 \cdot 2 \mathrm{pmol}$ primer (Andrews \& Patel, 1996) and $2.5 \mu \mathrm{g}$ BSA. Thermal cycling was carried out using a Rapid Cycler (Idaho Technology) at a temperature transition slope of 2 , an initial denaturation of $94^{\circ} \mathrm{C}$ for $15 \mathrm{~s}$, then 25 cycles of denaturation at $94^{\circ} \mathrm{C}$ for $0 \mathrm{~s}$, annealing at $50^{\circ} \mathrm{C}$ for $10 \mathrm{~s}$ and extension at $60^{\circ} \mathrm{C}$ for $3 \mathrm{~min}$.

Sequence alignments and phylogenetic inferences. The new sequence data that were generated were aligned and checked for accuracy manually with the alignment editor ae2 (Maidak et al., 1996). The program BLAST (Altschul et al., 1997) was initially used against the GenBank database to determine if any newly released, closely related sequences existed in the database. For analysis, the sequences of Anaerobaculum thermoterrenum and $D$. peptidovorans were extracted from GenBank (nos U50711 and U52817, respectively) and manually aligned with the prealigned sequences obtained from the Ribosomal Database Project (Maidak et al., 1996). Pairwise evolutionary distances based on 1151 unambiguous nucleotides were computed using DNADIST (Jukes \& Cantor option) and neighbour-joining programs that form part of the PHYLIP package (Felsenstein, 1993). TREECON was used extensively for bootstrap analysis (500 data sets) (Van de Peer \& De Wachter, 1993).

\section{RESULTS}

\section{Isolation}

The highest dilution showing growth on glutamate after 3-4 weeks incubation at $37^{\circ} \mathrm{C}$ was used for further isolation. This positive culture was serially diluted and inoculated into roll tubes. Only one type of colony (small, round, whitish with smooth edges) developed after 4 weeks incubation at $37^{\circ} \mathrm{C}$. Several colonies were picked and a pure culture derived from one colony was selected, designated strain GLU-3 ${ }^{\mathrm{T}}$ and characterized further. Strain GLU-3 ${ }^{\mathrm{T}}$ grew slowly in medium containing glutamate and yeast extract, a
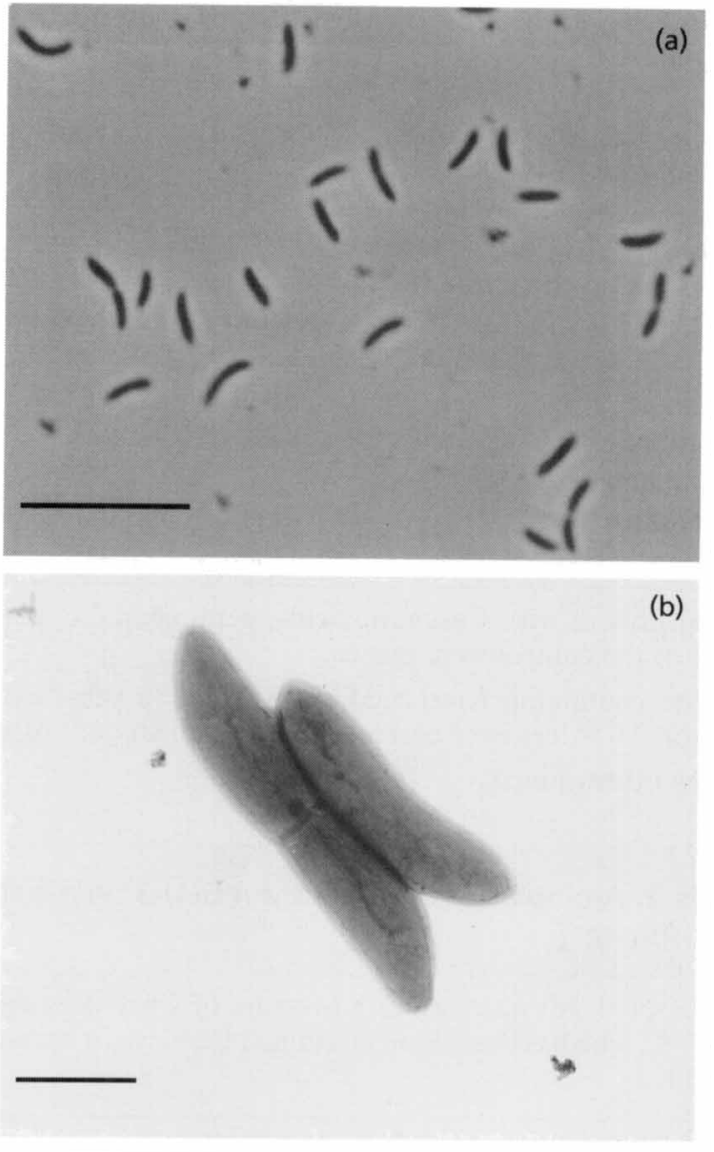

(c)

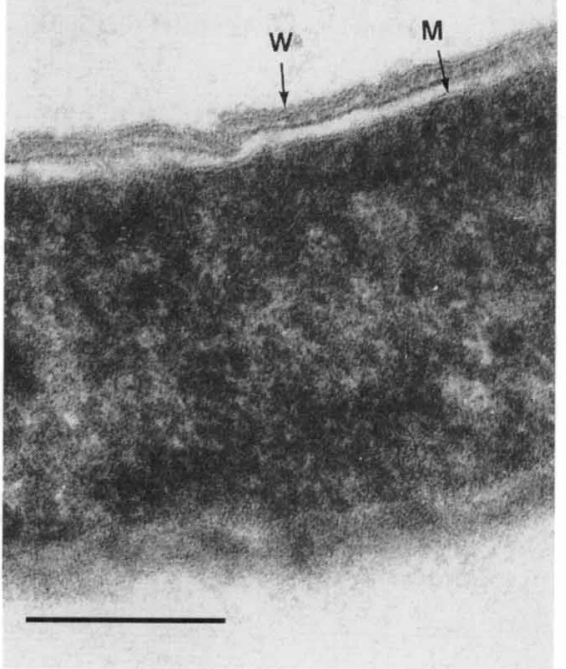

Fig. 1. (a) Phase-contrast photomicrograph of cells from the exponential growth phase of strain GLU-3 ${ }^{\top}$. Bar, $10 \mu \mathrm{m}$. (b) Transmission electron micrograph of negatively stained cells of strain GLU-3 $3^{\top}$. Bar, $1 \mu \mathrm{m}$. (c) Transmission electron micrograph of the cell wall of strain GLU-3 ${ }^{\top}$ showing a multi-layered structure (W) and cytoplasmic membrane (M). Bar, $0.2 \mu \mathrm{m}$.

medium used to initiate isolations. Subsequent experiments revealed that strain GLU-3 ${ }^{\mathrm{T}}$ grew much better with arginine as the energy source, and therefore this 
Table 1. Fermentation of substrates that supported growth of strain GLU-3T in pure culture

Results were recorded after 3 weeks incubation at $37^{\circ} \mathrm{C}$. The basal medium contained $0 \cdot 2 \%$ yeast extract.

\begin{tabular}{|c|c|c|c|c|c|c|c|}
\hline \multirow[t]{2}{*}{ Substrate* } & \multirow{2}{*}{$\begin{array}{c}\text { Amino acid } \\
\text { degraded (mM) }\end{array}$} & \multicolumn{5}{|c|}{ Products formed $(\mathbf{m M}) \dagger$} & \multirow[t]{2}{*}{$\Delta O D_{580}$} \\
\hline & & Acetate & Propionate & Formate & Ornithine & $\mathbf{H}_{2}$ & \\
\hline Arginine & $6 \cdot 1$ & $1 \cdot 0$ & $0 \cdot 0$ & $2 \cdot 5$ & 4.7 & + & 0.240 \\
\hline Histidine & ND & $9 \cdot 2$ & $0 \cdot 0$ & $4 \cdot 8$ & $0 \cdot 0$ & ND & 0.220 \\
\hline Glutamate & $7 \cdot 7$ & $7 \cdot 5$ & $2 \cdot 0$ & $4 \cdot 0$ & $0 \cdot 0$ & + & 0.080 \\
\hline Threonine & ND & $9 \cdot 4$ & 0.0 & $0 \cdot 0$ & $0 \cdot 0$ & ND & $0 \cdot 110$ \\
\hline Glycine & $3 \cdot 0$ & $4 \cdot 5$ & $0 \cdot 0$ & $0 \cdot 0$ & $0 \cdot 0$ & ND & $0 \cdot 082$ \\
\hline
\end{tabular}

* Poor growth with Casamino acids, peptone and cysteine was observed and acetate levels above those of the control were present.

$\dagger$ Tubes containing basal medium with $0 \cdot 2 \%$ yeast extract but lacking substrates were used as control. All values were corrected for a small amount of acetate $(2 \mathrm{mM})$ formed in the control tubes. ND, Not determined.

Table 2. Amino acids used by strain GLU- $3^{\top}$ in mixed culture and under a hydrogen atmosphere

$\mathrm{H}_{2} / \mathrm{CO}_{2}(80: 20)$ was used at a pressure of 2 bar. Results were recorded after 3 weeks incubation at $37^{\circ} \mathrm{C}$. The basal medium contained $0.2 \%$ yeast extract and substrates at concentrations indicated.

\begin{tabular}{|c|c|c|c|c|c|c|c|c|}
\hline \multirow{2}{*}{$\begin{array}{l}\text { Culture } \\
\text { conditions }\end{array}$} & \multirow{2}{*}{$\begin{array}{l}\text { Amino acid } \\
\text { degraded } \\
\text { (mM) }\end{array}$} & \multicolumn{6}{|c|}{ Products formed ${ }^{*}$} & \multirow[t]{2}{*}{$\Delta \mathrm{OD}_{580}$} \\
\hline & & Acetate & Propionate & Formate & Ornithine & $\mathrm{H}_{2}$ & $\mathbf{C H}_{4}$ & \\
\hline $\begin{array}{c}\text { Arginine }+M \\
\text { formicicum }\end{array}$ & 8.9 & $2 \cdot 2$ & $6 \cdot 0$ & $0 \cdot 0$ & $0 \cdot 0$ & $0 \cdot 0$ & $3 \cdot 80$ & $0 \cdot 260$ \\
\hline Arginine $+\mathrm{H}_{2}$ & ND & 1.0 & $0 \cdot 0$ & $3 \cdot 0$ & ND & ND & 0.00 & $0 \cdot 202$ \\
\hline $\begin{array}{l}\text { Histidine }+M \text {. } \\
\text { formicicum }\end{array}$ & $6 \cdot 2$ & $4 \cdot 0$ & $3 \cdot 3$ & $0 \cdot 0$ & $0 \cdot 0$ & $0 \cdot 0$ & $1 \cdot 72$ & $0 \cdot 330$ \\
\hline Histidine $+\mathrm{H}_{2}$ & ND & $5 \cdot 0$ & $0 \cdot 0$ & $4 \cdot 0$ & $0 \cdot 0$ & ND & 0.00 & $0 \cdot 200$ \\
\hline $\begin{array}{l}\text { Glutamate }+M \text {. } \\
\text { formicicum }\end{array}$ & $7 \cdot 0$ & 1.5 & $7 \cdot 0$ & $0 \cdot 0$ & $0 \cdot 0$ & $0 \cdot 0$ & $2 \cdot 60$ & $0 \cdot 180$ \\
\hline Glutamate $+\mathrm{H}_{2}$ & $6 \cdot 0$ & $6 \cdot 5$ & 0.0 & $5 \cdot 1$ & $0 \cdot 0$ & ND & 0.00 & 0.072 \\
\hline
\end{tabular}

* Tubes containing basal medium with $0.2 \%$ yeast extract but lacking substrates were used as control. All values were corrected for the small amounts of acetate $(2 \mathrm{mM})$ formed in the control tubes. Acetate, propionate, formate, ornithine and $\mathrm{H}_{2}$ were determined in $\mathrm{mM}$ and $\mathrm{CH}_{4}$ was determined in mmol.

ND, Not determined.

amino acid was used for determining optimal growth conditions for strain GLU-3 $3^{\mathrm{T}}$.

\section{Morphology}

Cells of strain GLU-3 $3^{\mathrm{T}}$ stained Gram-negative. They were slightly curved rods and measured $4 \cdot 0-6 \cdot 0$ by $0.3-0.4 \mu \mathrm{m}$ when grown on a medium containing arginine and yeast extract (Fig. 1a, b). Motility was not observed and electron microscopy of negatively stained cells revealed the absence of flagella. Spores were not observed from cells grown under various conditions and cells were not heat resistant. Ultrathin sections of strain GLU-3 ${ }^{\mathrm{T}}$ revealed a cytoplasmic membrane and a complex cell wall layer characteristic of a Gram-negative cell (Fig. 1c).

\section{Growth, metabolic properties and $\mathrm{G}+\mathrm{C}$ content}

Strain GLU-3 ${ }^{T}$ was a strictly anaerobic, chemoorganotrophic bacterium. The optimal growth temperature was $35^{\circ} \mathrm{C}$ and the temperature range for 


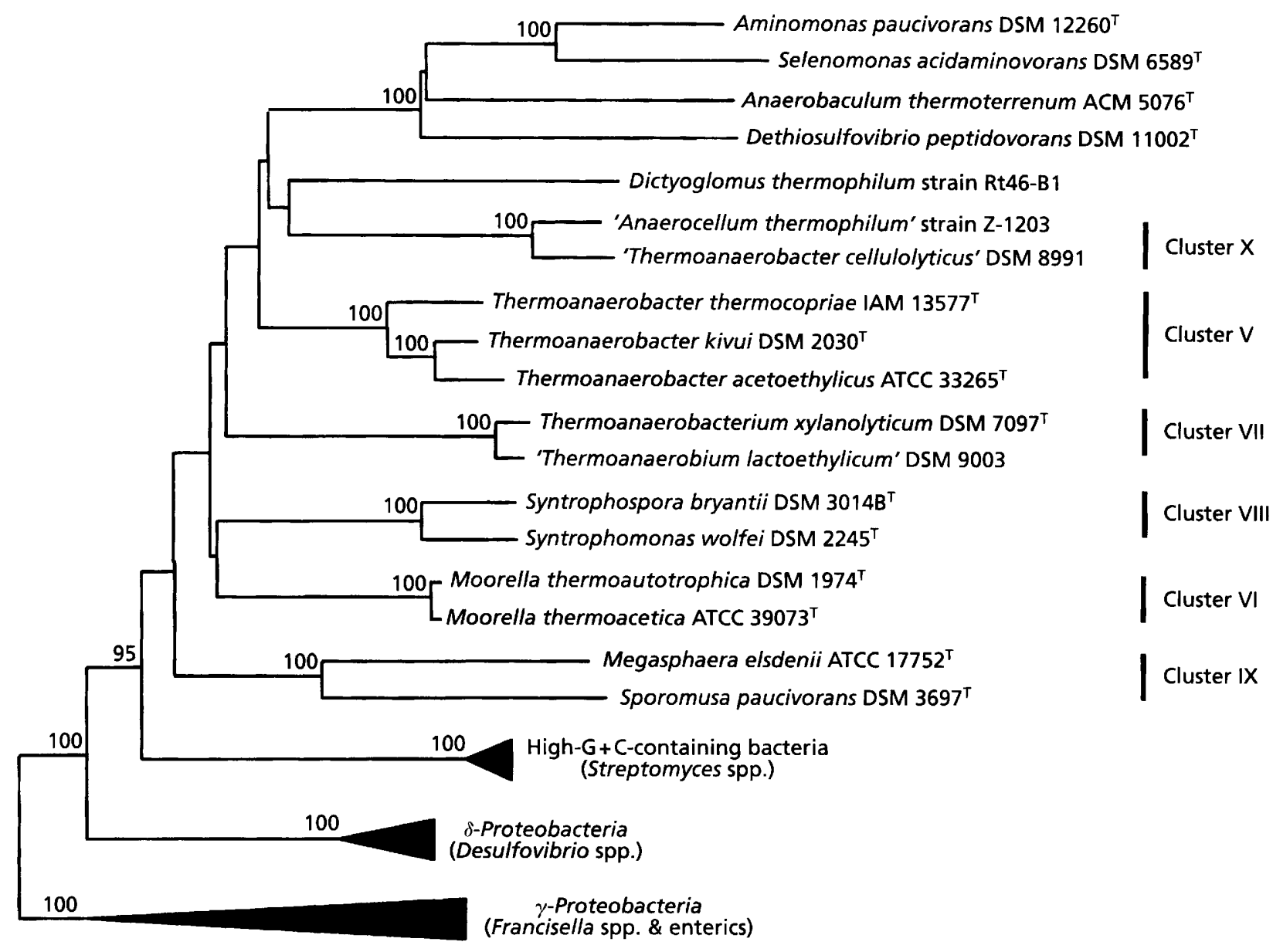

$10 \%$

Fig. 2. Unrooted phylogenetic dendrogram based on $16 S$ rRNA sequence data indicating the position of Aminomonas paucivorans strain GLU-3 ${ }^{\top}$ within the radiation of representatives of the low G+C-DNA-containing Gram-positive bacteria. All the sequences used in the analysis, with the exception of sequences of Anaerobaculum thermoterrenum and Dethiosulfovibrio peptidovorans (GenBank nos U50711 and U52817, respectively) were obtained from the Ribosomal Database Project, version 5.0 (Maidak et al., 1996). Pairwise evolutionary distances based on 1151 unambiguous nucleotides were computed using DNADIST (Jukes \& Cantor option) and neighbour-joining programs that form part of the PHYLIP package (Felsenstein, 1993). TREECON was used for bootstrap analysis (500 data sets) (Van de Peer \& De Wachter, 1993) and only values greater than $90 \%$ were considered significant and are therefore reported. Scale bar, 10 nucleotide substitutions per 100 nucleotides.

growth was between 20 and $40^{\circ} \mathrm{C}$; no growth was observed at 18 and $42^{\circ} \mathrm{C}$. Strain GLU-3 $3^{\mathrm{T}}$ did not require $\mathrm{NaCl}$ for growth, but tolerated up to $2.0 \%$ $\mathrm{NaCl}$, with optimum growth occurring in the presence of $0.05-0.50 \% \mathrm{NaCl}$. The $\mathrm{pH}$ range for growth was $6 \cdot 7-8 \cdot 3$ with an optimum around $7 \cdot 5$.

The $\mathrm{G}+\mathrm{C}$ content of strain GLU- $3^{\mathrm{T}}$ was $43 \mathrm{~mol} \%$.

\section{Substrates used for growth}

Strain GLU $-3^{\mathrm{T}}$ did not grow in basal medium without yeast extract and $0.2 \%$ yeast extract was routinely used for substrate utilization tests. Strain GLU-3 $3^{T}$ fermented arginine, histidine, glutamate, threonine and glycine (Table 1). Arginine was fermented to ornithine, acetate and formate, histidine was fermented to acetate and formate, and glutamate was fermented to acetate and, to a minor extent, propionate and formate. Threonine and glycine were degraded to acetate. Acetate was also the major end-product of metabolism from Casamino acids, peptone and cysteine, but they were poorly used. As we have used $0.2 \%$ yeast extract to test for the utilization of amino acids, we cannot rule out the possibility that degradation occurs via the Stickland reaction, especially in the case of glycine. The following substrates were not used by strain GLU- $3^{\mathrm{T}}$ : leucine, isoleucine, valine, alanine, lysine, proline, serine, methionine, asparagine, tyrosine, phenylalanine, aspartate, gelatin, 
casein, glucose, saccharose, ribose, xylose, cellobiose, melibiose, maltose, galactose, mannose, arabinose, rhamnose, lactose, sorbose, mannitol, acetate, propionate, butyrate, valerate, fumarate, malate, succinate, pyruvate, lactate, citrate, $\alpha$-ketoglutarate, mesaconate, $\beta$-methylaspartate, oxaloacetate, glycerol and ethanol. Sulfate, thiosulfate, elemental sulfur, sulfite, nitrate and fumarate were not utilized as electron acceptors.

\section{Amino acid degradation in mixed cultures}

A mixed culture of strain GLU $-3^{\mathrm{T}}$ and $M$. formicicum was unable to extend the range of utilizable substrates. However, compared to pure cultures, association of strain GLU- $3^{\mathrm{T}}$ with $M$. formicicum resulted in a shift in end-product formation during degradation of arginine, histidine and glutamate with methane and propionate as the major fermentation products (Table 2 ). In contrast to the pure culture, ornithine did not accumulate during arginine degradation by the mixed culture. Methane was not detectable in mixed culture with glycine and threonine, and the same end-product profile as for a pure culture was observed (data not shown).

\section{Growth under hydrogen atmosphere}

Cultivation of strain GLU-3 $3^{\mathrm{T}}$ under a $\mathrm{H}_{2} / \mathrm{CO}_{2}(80: 20)$ atmosphere did not affect the fermentation of arginine, histidine, glutamate, threonine or glycine; the endproducts were similar to those found without a hydrogen atmosphere (Table 2 and data not shown).

\section{$16 \mathrm{~S}$ rRNA sequence analysis}

An almost complete $16 \mathrm{~S}$ rRNA gene sequence (1504, 1426 and 1530 nucleotides) of strain GLU-3 ${ }^{\mathrm{T}}, S$. acidaminovorans and ' $S$. acidaminophila' corresponding to positions 17-1539, 14-1540 and 17-1539, respectively $[E$. coli numbering; according to Winker $\&$ Woese (1991)] were determined. Initial sequence comparisons indicated that strain GLU-3 ${ }^{\mathrm{T}}$ was a member of the low $\mathrm{G}+\mathrm{C}$, Gram-positive branch. Several phylogenetic trees were generated using numerous combinations of sequences from the members of this branch and strain GLU- $3^{\mathrm{T}}$ was consistently placed as an independent branch of descent adjacent to members of cluster $\mathrm{V}$. This cluster currently comprises Thermoanaerobacter species, $D$. peptidovorans and $S$. acidaminovorans (Fig. 2). The closest relative of strain GLU- $3^{\mathrm{T}}$ was $S$. acidaminovorans (similarity of $89.5 \%$ ), which also forms an independent lineage in the vicinity of cluster V. Bootstrap analysis indicates a robust relationship between strain GLU-3 ${ }^{\mathrm{T}}$ and $S$. acidaminovorans $(100 \%)$. Comparison of the sequence of the $16 \mathrm{~S}$ rRNA gene of $S$. acidaminophila with that of members of the low $\mathrm{G}+\mathrm{C}$, Gram-positive branch indicated that it clustered with Clostridium quercicolum, a member of cluster IX (Collins et al., 1994), with a similarity of
$90 \%$, rather than in the vicinity of cluster $\mathrm{V}$, and was therefore not related to strain GLU-3 ${ }^{\mathrm{T}}$.

\section{DISCUSSION}

Strain GLU-3 ${ }^{\mathrm{T}}$ is a Gram-negative, slightly curved, non-spore-forming, obligate amino-acid-degrading anaerobe and therefore cannot be assigned to the aminolytic members of the genus Clostridium which include Clostridium sticklandii and Clostridium aminophilum (Paster et al., 1993), Clostridium litorale, Clostridium pascui and Clostridium hydroxybenzoicum (Fendrich et al., 1990; Wilde et al., 1997; Zhang et al., 1994) and Clostridium acetireducens (Örlygsson et al., 1996). These species are Gram-positive, sporeforming, straight rods. This conclusion is confirmed by phylogenetic analysis which places strain GLU $3^{\mathrm{T}}$ in the low-G + C-containing phylum in the vicinity of Thermoanaerobacter (cluster V), S. acidaminovorans and $D$. peptidovorans, with $S$. acidaminovorans being its closest relative. Like strain GLU-3 ${ }^{\mathrm{T}}$, Thermoanaerobacter species, $S$. acidaminovorans and $D$. peptidovorans use amino acids. However, Thermoanaerobacter species and $S$. acidaminovorans are thermophiles which also utilize carbohydrates, but in addition, $D$. peptidovorans, uses thiosulfate or elemental sulfur as the electron acceptor and strain GLU-3 ${ }^{\mathrm{T}}$ does not.

Very little is understood about amino-acid-degrading pathways operating in obligately aminolytic anaerobes. Strain GLU-3 ${ }^{\mathrm{T}}$ fermented histidine to acetate and formate. This fermentative pathway, albeit poorly studied, is similar to that used by aerobic bacteria as suggested by McSweeny et al. (1993) and may also be operating in strain GLU- $3^{\mathrm{T}}$. Strain GLU$3^{\mathrm{T}}$ degraded arginine to ornithine and this characteristic is similar to that reported for S. acidaminovorans and Synergistes jonesii strain 78-1 (McSweeny et al., 1993). This suggests that the arginine deaminase pathway may be operational in strain GLU-3 ${ }^{\mathrm{T}}$

In pure culture, strain GLU $-3^{\mathrm{T}}$ fermented glutamate to acetate, formate and trace amounts of propionate, a property that closely resembles $A$. hydrogenoformans in pure culture (Stams \& Hansen, 1984). This trait differentiates it from other amino-acid-degrading members of the genera Acidaminococcus, Peptostreptococcus, Fusobacterium and Clostridium (Rogosa, 1969; Barker, 1981; Wilde et al., 1997), which produce acetate, butyrate, carbon dioxide, ammonium and hydrogen. In contrast to strain GLU$3^{\mathrm{T}}$, S. acidaminovorans (Guangsheng et al., 1992) and ' $S$. acidaminophila' (Nanninga et al., 1987) produce propionate as a major end-product from glutamate fermentation. Acetate was the only fatty acid produced from threonine and glycine fermentation. In the case of threonine degradation, this end-product is unusual as most species that degrade threonine, with the exception of a few examples such as $C$. sticklandii and Clostridium subterminale (Barker, 1981), are known to produce acetate and propionate. 


\section{Degradation of amino acids in mixed culture}

An increase in the range of amino acids utilized was not observed in mixed culture with $M$. formicicum, in contrast to the situation observed for $A$. hydrogenoformans, S. acidaminovorans and E. acidaminophilum (Zindel et al., 1988). However, the metabolism of all the amino acids used by strain GLU- $3^{\mathrm{T}}$, except threonine and glycine, is clearly influenced by the presence of the hydrogenotrophic methanogen. No increase in acetate production, no change in the endproduct profile, and the lack of methane production in the presence of the hydrogen scavenger suggest that threonine and glycine degradation occurs via a reductive rather than an oxidative process. In addition, a hydrogen gas phase did not alter the growth of strain GLU $-3^{\mathrm{T}}$ on these two substrates further strengthening our hypothesis.

Co-culture of strain GLU-3 $3^{\mathrm{T}}$ with $M$. formicicum shifted the metabolic end-products of arginine, histidine and glutamate degradation from acetate to propionate as the major end-product. This trait is similar to that of $A$. hydrogenoformans when it is cocultured on glutamate and histidine with a hydrogen scavenger (Stams \& Hansen, 1984). This may occur because the partial pressure of $\mathrm{H}_{2}$ is reduced due to consumption by the hydrogen scavenger, with propionate production becoming thermodynamically more favourable (McInerney, 1988).

In spite of observed similarities between strain GLU$3^{\mathrm{T}}$ and $A$. hydrogenoformans with respect to glutamate metabolism, the latter is inhibited by a hydrogen atmosphere when grown on this amino acid. In addition, there are marked differences in the amino acids utilized. For example, $A$. hydrogenoformans utilized arginine and threonine only in mixed culture with hydrogenotrophic bacteria (Stams \& Hansen, 1984), whereas strain GLU-3 ${ }^{\text {T }}$ could ferment both these amino acids in pure culture. In addition, unlike A. hydrogenoformans, strain GLU $-3^{\mathrm{T}}$ did not utilize alanine, valine, leucine or isoleucine in the presence of hydrogen scavenging bacteria.

Because of the marked phenotypic and phylogenetic differences of strain GLU- $3^{\mathrm{T}}$ from other amino acid degraders, we propose that it be assigned as a new species of a new genus Aminomonas paucivorans gen. nov., sp. nov.

\section{Description of Aminomonas gen. nov.}

Aminomonas (a.mi.no.mo'nas. M.L. aminum amine; Gr. n. monas a unit, monad; M.L. fem. n. Aminomonas amine-degrading monads).

In bacterial taxonomy, the epithet 'Amino-' has always been related to amino acid fermentation rather than amine utilization. For the sake of clarity, it would be best if the epithet 'Amino-' is reserved for amino acids rather than being linked with amines. Strictly anaerobic, non-spore-forming, mesophilic, curved rods. Stains Gram-negative. Grows by utilizing amino acids only in the presence of yeast extract. Forms a new line of descent in the low- $\mathrm{G}+\mathrm{C}$-containing branch adjacent to cluster $\mathrm{V}$ based on 16S rRNA sequence analysis. Habitat: anaerobic sludge of a dairy wastewater treatment plant. The type species is Aminomonas paucivorans.

\section{Description of Aminomonas paucivorans sp. nov.}

Aminomonas paucivorans (pau'ci.vor'ans. L. adj. paucus few, little; L. pres. part. vorans devouring, digesting; L. paucivorans digesting little).

Slightly curved, rod-shaped bacterium $(0 \cdot 3$ by $4 \cdot 0$ $6.0 \mu \mathrm{m}$ ) which occurs singly or in pairs. Asaccharolytic, stains Gram-negative, non-spore-forming. Strictly anaerobic. Colonies (up to $1.0 \mathrm{~mm}$ ) are round, smooth and white. Mesophilic. Optimal growth temperature $35^{\circ} \mathrm{C}$, range for growth $20-40^{\circ} \mathrm{C} ; \mathrm{pH}$ range of $6 \cdot 7-8 \cdot 3$, optimum $\mathrm{pH} 7 \cdot 5$; does not require $\mathrm{NaCl}$ for growth but tolerates up to $2.0 \%$ with optimum growth occurring between $0.05-0.50 \% \mathrm{NaCl}$. Yeast extract is required for growth. Ferments arginine, threonine, glutamate, histidine and glycine. In mixed culture with $M$. formicicum on glutamate, arginine and histidine, a shift of end-products from acetate to propionate as the major end-product occurs. No growth was observed on carbohydrates, gelatin, casein, pyruvate, succinate, malate, fumarate, $\alpha$-ketoglutarate, mesaconate, $\beta$ methylaspartate, oxaloacetate, glycerol, ethanol, acetate, propionate, butyrate, lactate, citrate, leucine, lysine, alanine, valine, proline, serine, methionine, asparagine, phenylalanine and aspartate. Sulfate, thiosulfate, elemental sulfur, sulfite, nitrate and fumarate were not utilized as electron acceptors. The $\mathrm{G}+\mathrm{C}$ content of the DNA is $43 \mathrm{~mol} \%$. The type strain is GLU $-3^{\mathrm{T}}$ ( = DSM $12260^{\mathrm{T}}$ ). Isolated from anaerobic sludge of a dairy wastewater treatment plant of SantaFe de Bogota, Colombia. Adverse effects on animals and humans are not known. Because of the ability of Aminomonas paucivorans to degrade amino acids and peptides, the possibility of harmful effects cannot be excluded. Cautious handling and autoclaving of cultures before disposal is recommended.

\section{ACKNOWLEDGEMENTS}

We thank N. Zylber (BIP-CNRS) for amino acid analysis. This work was supported by grants from French Foreign Office (PCP) and Instituto Colombiano para el desarrollo de la Ciencia y la Tecnologia (COLCIENCIAS) (to S. B.) and in part from the Australian Research Council (to B.K.C.P.). We would like to thank Professor Trüper for having brought the bacterial nomenclature rules to our attention via the peer review process.

\section{REFERENCES}

Altschul, S. F., Madden, T. L., Schaffer, A. A., Zhang, J., Zhang, Z., Miller, W. \& Lipman, D. J. (1997). Gapped BLAST and PSI-BLAST: a new generation of protein database search programs. Nucleic Acids Res 25, 3389-3402. 
Andrews, K. T. \& Patel, B. K. C. (1996). Fervidobacterium gondwanense sp. nov., a new thermophilic anaerobic bacterium isolated from nonvolcanically heated geothermal waters of the Great Artesian Basin of Australia. Int $J$ Syst Bacteriol 46, 265-269.

Balch, W. E., Fox, G. E., Magrum, R. J. \& Wolfe, R. S. (1979). Methanogens: re-evaluation of a unique biological group. Microbiol Rev 43, 260-296.

Barker, H. A. (1981). Amino acid degradation by anaerobic bacteria. Annu Rev Biochem 50, 23-40.

Chen, G. \& Russell, J. M. (1988). Fermentation of peptides and amino acids by a monensin-sensitive ruminal Peptostreptococcus. Appl Environ Microbiol 54, 2742-2749.

Chen, G. \& Russell, J. M. (1989). More monensin-sensitive, ammonia-producing bacteria from the rumen. Appl Environ Microbiol 55, 1052-1057.

Collins, M. D., Lawson, P. A., Willems, A., Cordoba, J. J., Fernandez-Garayzabal, J., Garcia, P., Cai, J. \& Farrow, J. A. E. (1994). The phylogeny of the genus Clostridium: proposal of five new genera and eleven new species combinations. Int $J$ Syst Bacteriol 44, 812-826.

Fardeau, M. L., Cayol, J. L., Magot, M. \& Ollivier, B. (1993). $\mathrm{H}_{2}$ oxidation in the presence of thiosulfate by a Thermoanaerobacter strain isolated from a oil-producing well. FEMS Microbiol Lett 13, 327-332.

Fardeau, M.-L., Ollivier, B., Patel, B. K. C., Magot, M., Thomas, P., Rimbault, A., Rocchiccioli, F. \& Garcia, J.-L. (1997). Thermotoga hypogea sp. nov., a xylanolytic, thermophilic bacterium from an oil-producing well. Int J Syst Bacteriol 47, 1013-1019.

Felsenstein, J. (1993). PHYLIP (Phylogenetic Inference Package) version 3.51c. Department of Genetics, University of Washington, Seattle, WA, USA.

Fendrich, C., Hippe, H. \& Gottschalk, G. (1990). Clostridium halophilium sp. nov. and $C$. litorale sp. nov., an obligate halophilic and a marine species degrading betaine in the Stickland reaction. Arch Microbiol 154, 127-132.

Guangsheng, C., Plugge, C. M., Roelofsen, W., Houwen, F. P. \& Stams, A. J. M. (1992). Selenomonas acidaminovorans sp. nov., a versatile thermophilic proton-reducing anaerobe able to grow by decarboxylation of succinate to propionate. Arch Microbiol 157, 169-175.

Hungate, R. E. (1969). A roll tube method for the cultivation of strict anaerobes. Methods Microbiol 3B, 117-132.

Imhoff-Stuckle, D. \& Pfenning, N. (1983). Isolation and characterization of a nicotinic acid-degrading sulfate-reducing bacterium, Desulfococcus niacini. Arch Microbiol 136, 194-198.

Mclnerney, M. J. (1988). Anaerobic hydrolysis and fermentation of fats and proteins. In Biology of Anaerobic Organisms, pp. 373-415. Edited by A. J. B. Zender. New York: Wiley.

McSweeny, C. S., Allison, M. J. \& Mackie, R. I. (1993). Amino acid utilization by the ruminal bacterium Synergistes jonesii strain 78-1. Arch Microbiol 159, 131-135.

Magot, M., Ravot, G., Campaignolle, X., Ollivier, B., Patel, B. K. C., Fardeau, M.-L., Thomas, P., Crolet, J.-L. \& Garcia, J.-L. (1997). Dethiosulfovibrio peptidovorans gen. nov., sp. nov., a new anaerobic, slightly halophilic, thiosulfate-reducing bacterium from corroding offshore oil wells. Int $J$ Syst Bacteriol 47, $818-824$.
Maidak, B. L., Olsen, G. J., Larsen, N., Overbeek, R., McCaughey, M. J. \& Woese, C. R. (1996). The Ribosomal Database Project (RDP). Nucleic Acids Res 24, 82-85.

Mesbah, M., Premachandran, U. \& Whitman, W. B. (1989). Precise measurement of the $\mathrm{G}+\mathrm{C}$ content of deoxyribonucleic acid by high-performance liquid chromatography. Int J Syst Bacteriol 39, 159-167.

Moore, S., Spackman, D. H. \& Stein, W. H. (1958). Chromatography of amino acids on sulfonated polystyrene resins: an improved system. Anal Chem 30, 1158-1190.

Nanninga, H. J., Drent, W. J. \& Gottschal, J. C. (1987). Fermentation of glutamate by Selenomonas acidaminophila sp. nov. Arch Microbiol 147, 152-157.

Örlygsson, J., Krooneman, J., Collins, M. D., Pascual, C. \& Gottschal, J. C. (1996). Clostridium acetireducens sp. nov., a novel amino acid-oxidizing, acetate-reducing anaerobic bacterium. Int J Syst Bacteriol 46, 454-459.

Paster, B. J., Russell, J. B., Yang, C. M., Chow, J. J. M., Woese, C. R. \& Tanner, R. (1993). Phylogeny of the ammonia-producing ruminal bacteria Peptostreptococcus anaerobius, Clostridium sticklandii, and Clostridium aminophilum sp. nov. Int J Syst Bacteriol 43, 107-110.

Redburn, A. C. \& Patel, B. K. C. (1993). Phylogenetic analysis of Desulfotomaculum thermobenzoicum using polymerase chain reaction-amplified 16S rRNA-specific DNA. FEMS Microbiol Lett 113, 81-86.

Rogosa, M. (1969). Acidaminococcus gen. nov., Acidaminococcus fermentans sp. nov., an anaerobic Gram-negative diplococci using amino acids as the sole energy source for growth. $J$ Bacteriol 98, 756-766.

Smith, E. A. \& MacFarlane, G. T. (1997). Dissimilatory amino acid metabolism in human colonic bacteria. Anaerobe 3, 327-337.

Stams, A. J. M. \& Hansen, T. A. (1984). Fermentation of glutamate and other compounds by Acidaminobacter hydrogenoformans gen. nov. sp. nov., an obligate anaerobe isolated from black mud. Studies with pure cultures and cocultures with sulfate-reducing and methanogenic bacteria. Arch Microbiol 137, 329-337.

Van de Peer, Y. \& De Wachter, R. (1993). TREeCON: a software package for the construction and drawing of evolutionary trees. Comput Appl Biosci 9, 177-182.

Wilde, E., Collins, M. D. \& Hippe, H. (1997). Clostridium pascui sp. nov., a new glutamate-fermenting sporeformer from a pasture in Pakistan. Int $J$ Syst Bacteriol 47, 164-170.

Winker, S. \& Woese, C. R. (1991). A definition of the domain Archaea, Bacteria and Eucarya in terms of small subunit ribosomal RNA characteristics. Syst Appl Microbiol 13, 161-165.

Zhang, X., Mandelco, L. \& Wiegel, J. (1994). Clostridium hydroxybenzoicum sp. nov., an amino acid-utilizing, hydroxybenzoate-decarboxylating bacterium isolated from methanogenic freshwater pond sediment. Int J Syst Bacteriol 44, 214-222.

Zindel, U., Freudenberg, W., Rieth, M., Andreesen, J. R., Schnell, J. \& Widdel, F. (1988). Eubacterium acidaminophilum sp. nov., a versatile amino acid-degrading anaerobe producing or utilizing $\mathrm{H}_{2}$ or formate. Arch Microbiol 150, 254-266. 